\author{
Matgorzata Orzet-Górniak \\ Uniwersytet Marii Curie-Skłodowskiej w Lublinie \\ Wydział Pedagogiki i Psychologii \\ Instytut Psychologii \\ 20-085 Lublin, Pl. Litewski 5
}

\title{
Antyspołeczne zaburzenia osobowości a skuteczność oddziaływań terapeutycznych i resocjalizacyjnych
}

\section{Streszczenie}

Antyspołeczne zaburzenia osobowości należą do tej kategorii dysfunkcji psychicznych człowieka, które skutkują jego nieprawidłowym zachowaniem, niejednokrotnie utrudniającym lub wręcz uniemożliwiającym przystosowanie do środowiska społecznego. Na gruncie oddziaływań resocjalizacyjnych oraz psychoterapeutycznych jednostki dotknięte tego typu zaburzeniem stanowią grupę wyjątkowo trudną i skomplikowaną. Niniejszy artykuł ma na celu zaprezentowanie zarówno polskich, jak i zagranicznych poglądów na temat skuteczności psychoterapii i resocjalizacji jednostek antyspołecznych. Stanowi on tym samym charakterystykę funkcjonowania psychospołecznego opisywanej tu grupy osób oraz prezentuje przegląd współczesnych badań odnoszących się do efektywności procesu resocjalizacji w ich zakresie.

Słowa kluczowe: antyspołeczne zaburzenia osobowości, psychopatia, terapia psychoanalityczna, terapia poznawczo-behawioralna.

\section{Istota antyspołecznych zaburzeń osobowości}

Zaburzenia osobowości należą do tej kategorii dysfunkcji psychicznych człowieka, które skutkują jego nieprawidłowym zachowaniem, niejednokrotnie utrudniającym lub wręcz uniemożliwiającym przystosowanie do środowiska zewnętrznego. Zgodnie z definicją Amerykańskiego Towarzystwa Psychiatrycznego DSM-IV-TR (Wciórka, 2008) termin osobowości zaburzonej odnosi się 
do utrwalonego wzorca wewnętrznego przeżywania i zachowania, wyraźnie odbiegającego od norm oraz oczekiwań charakterystycznych dla kultury, w której żyje dana jednostka. Wspomniany wzór ujawnia się ponadto w co najmniej dwóch z czterech obszarów funkcjonowania: poznawczym, afektywnym, interpersonalnym oraz w zakresie kontroli impulsów (Gawda, 2011). Istotne jest, że w przypadku niektórych typów osobowości nieprawidłowej niewłaściwe strategie adaptacyjne oraz dysfunkcjonalne przekonania skutkować mogą wchodzeniem jednostki w konflikt z prawem, a w konsekwencji jej bezwzględnym pozbawieniem wolności. Do tego właśnie rodzaju patologicznych osobowości, które stanowią jednocześnie grupę szczególnie wysokiego ryzyka podejmowania działalności kryminalnej zalicza się osobowość antyspołeczną.

W ramach wyjaśnienia zaznaczyć należy, że obecnie w literaturze psychiatryczno-psychologicznej obserwuje się tendencje do utożsamiania pojęcia osobowości antyspołecznej z terminem psychopatii, co implikuje szereg zarówno terminologicznych, jak i praktycznych rozbieżności w zakresie odpowiedniej diagnostyki (Pastwa-Wojciechowska, 2006), terapii, leczenia i resocjalizacji. Istotnym jest tu również fakt, że w polskiej rzeczywistości zauważa się wręcz wyjątkowo swobodne posługiwanie się etykietą psychopaty, co wydaje się nie mieć wyraźnych podstaw nie tylko teoretycznych, ale przede wszystkim klinicznych. Innymi słowy w praktyce terapeutycznej i resocjalizacyjnej ,poddajemy diagnozie jednostkę antyspołeczną, a czujemy psychopatę" (Millon, Davis, 2005), co z kolei niewątpliwie odzwierciedla się w nie do końca właściwych przeświadczeniach zarówno społeczeństwa, jak i przedstawicieli całego wymiaru sprawiedliwości o pełnej odporności tej właśnie grupy osób na wszelkiego rodzaju oddziaływania naprawcze.

W celu usystematyzowania powstałych rozbieżności terminologicznych należy wyraźnie podkreślić, że pojęcia psychopatii i antyspołecznych zaburzeń osobowości, choć z pewnością przejawiają zakresy wspólne, nie są w pełni równoznaczne (Pastwa-Wojciechowska, 2006). Kryteria rozpoznania psychopatii oparte na używanej obecnie skali obserwacyjnej psychopatii Roberta Hare'a (The Psychopathy Checklist-Revised - PCL-R) kreślą prototypowy obraz psychopaty jako osoby nie tylko antyspołecznej, na co wskazują m.in. jej ,wczesne problemy z zachowaniem, bogata historia kryminalna czy pasożytniczy styl życia" (Millon, Davis, 2005), ale również jako jednostkę wysoce skoncentrowaną na samym sobie i silnie narcystyczną, o czym świadczą takie cechy dodatkowe, jak: egocentryzm, poczucie wyższości, brak empatii czy też niezdolność do odczuwania wyrzutów sumienia (Millon, Davis, 2005).

Na zaprezentowanym rysunku widać wyraźnie, że chociaż każdy psychopata przejawia antyspołeczne zaburzenia osobowości, to jednak nie każda jednostka antyspołeczna wykazywać będzie charakterystyczne cechy psychopatii. Innymi słowy $\mathrm{w}$ naszym społeczeństwie funkcjonować mogą osoby z osobowością 
antyspołeczną, niebędące sensu stricte psychopatami. Co równie istotne, jednostki wykazujące antyspołeczne zaburzenia osobowości przejawiać mogą różne nasilenie cech psychopatycznych - od niskiego aż do bardzo silnego (tzw. „ciężka psychopatia") (za: Clarkin i in., 2013). Wiedza ta jest szczególnie istotna z punktu widzenia analizy uwarunkowań skłonności do podejmowania działań przestępczych, a tym samym z punktu widzenia prognozy planowanych efektów resocjalizacji, ogólnej podatności na leczenie oraz przewidywania prawdopodobnego ryzyka recydywy (Woodworth i in., 2002; Radochoński, 2005).

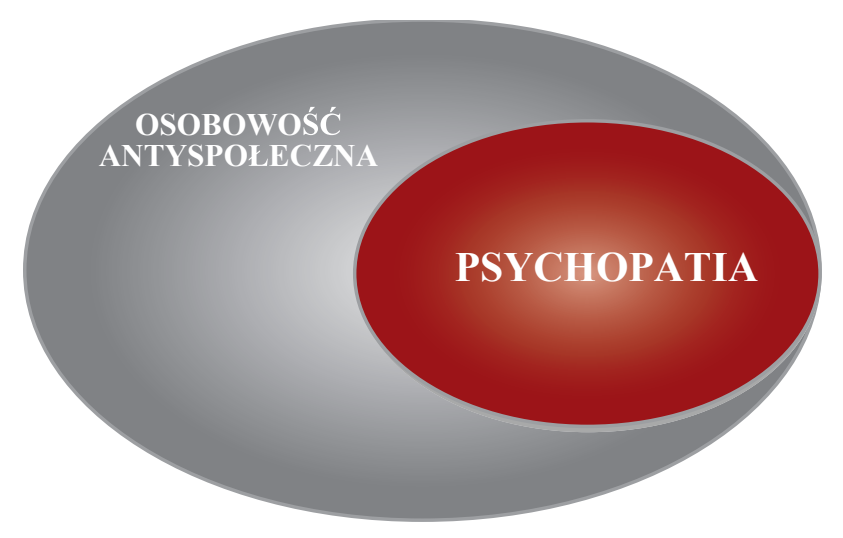

Rysunek 1. Zależność między antyspołecznym zaburzeniem osobowości a psychopatią Źródło: opracowanie własne

\section{Sprawca przestępstwa jako osoba $\mathrm{z}$ antyspołecznym zaburzeniem osobowości}

Fakt, że antyspołeczne zaburzenia osobowości należą do najbardziej kryminogennych dysfunkcji psychicznych człowieka nie powinien dziwić po przeanalizowaniu ich cech osiowych. „Nieumiejętność dostosowania się do norm społeczno-moralnych oraz prawnych, skłonność do oszustwa i zachowań manipulacyjno-instrumentalnych, brak wyrzutów sumienia, obojętność wobec ludzkiej krzywdy, jak również impulsywność, agresywność i całkowita nieodpowiedzialność" (Wciórka, 2000; Carson i in., 2003) bezpośrednio wskazują na bardzo duże prawdopodobieństwo wejścia jednostki antyspołecznej w konflikt z prawem. Taka konfiguracja symptomów składa się również na szczególną formę prowadzonej działalności kryminalnej i niewątpliwie różni się od przestępstw popełnianych przez osoby niewykazujące tego typu zaburzenia (Groth, 2010). Jest to także priorytetowy argument świadczący o powszechnej obecności antyspołecznych sprawców w zakładach karnych. 
W miejscu tym podkreślić należy, że problematyka obecności jednostek antyspołecznych w warunkach izolacji penitencjarnej z punktu widzenia oddziaływań naprawczych jest szczególnie istotna. Wspomniany trwały wzorzec nieprawidłowego funkcjonowania, jaki przejawiają jednostki antyspołeczne, równie mocno zaznacza się także na terenie zakładu karnego. Jak się ponadto okazuje warunki penitencjarne mogą wręcz nasilać istniejące już zaburzenia (Ciosek, 2001), eksponując tym samym zmniejszoną zdolność jednostek antyspołecznych w zakresie umiejętności dostosowywania się do ograniczeń, jakie środowisko inkarcerowane ze sobą niesie (Pastwa-Wojciechowska, 1998). Do szczególnie często obserwowanych zaburzeń w zakresie izolacji penitencjarnej zalicza się m.in.:

- niesubordynację oraz postawę opozycyjną względem władz więziennych (wynik wzmożonej pobudliwości);

- nieuzasadnioną podejrzliwość;

- brak samokrytycyzmu;

- defekt moralny przejawiający się szczególnym okrucieństwem wobec współwięźniów;

- zachowania instrumentalne przejawiające się w skłonności do samookaleczeń i głodówek (Pastwa-Wojciechowska, 1998).

Wszystkie te elementy wskazują wyraźnie na potrzebę objęcia osadzonych antyspołecznych zarówno szczególną uwagą służby penitencjarnej, jak również wysoce intensywnymi oddziaływaniami psychoterapeutycznymi. Przypuszczać można także, że pozytywne zmiany w zakresie terapii implikować będą pozytywne zmiany na gruncie resocjalizacji. Dlatego też w niniejszym artykule skupiono się na omówieniu terapii, których skuteczność stanowić będzie równoznacznik minimalizowania przestępczej aktywności.

\section{Terapia i resocjalizacja jednostek antyspołecznych}

Jednostki przejawiające antyspołeczne zaburzenia osobowości stanowią ogromne wyzwanie nie tylko dla klinicystów, ale również dla całego wymiaru sprawiedliwości. Jest to szczególnie widoczne przy istniejącym ogólnym przekonaniu o pełnej odporności tej właśnie grupy osób względem stosowanego wobec nich leczenia lub wręcz o możliwości pogorszenia ich ogólnego stanu funkcjonowania w wyniku błędnie podjętych oddziaływań terapeutycznych (Kent, Hoffmann, 2011). Literatura przedmiotu niejednokrotnie wskazuje na fakt, że żaden z istniejących aktualnie tradycyjnych bądź nietradycyjnych modelów terapeutycznych nie jest w stanie w pełni skutecznie poprawić funkcjonowania osób antyspołecznych, co potęguje jednocześnie pejoratywne powszechne przeświadczenia, że zaburzenie to jest nieuleczalne (Kent, Hoffmann, 2011). Pomimo utrzymujących się przez wiele lat tak pesymistycznych przekonań, obecnie pojawiły się już badania 
m.in. Davidson i in. (2009), Cullen i in. (2010), na podstawie których stwierdzić można, że nie ma przekonujących dowodów na nieuleczalny charakter antyspołecznych zaburzeń osobowości. Wyniki tych badań (zaprezentowane w dalszej części pracy) wskazują wyraźnie, że jednostki antyspołeczne mogą być podatne na pozytywne zmiany. Konieczne jest tu jednak zastosowanie odpowiednio intensywnej procedury terapeutycznej i właściwego podejścia terapeuty (Scott, 2001; Polaschek i Ross, 2010).

\subsection{Podstawowe trudności w zakresie prowadzenia i leczenia jednostek antyspołecznych}

Pomimo istniejących aktualnie dowodów klinicznych i empirycznych potwierdzających słuszność podejmowania względem osób antyspołecznych oddziaływań naprawczych, nie wyklucza to jednak faktu, że praca terapeutyczna z tą właśnie grupą osób należy do jednej z najbardziej problematycznych, a stosowane tu procedury postępowania do wyjątkowo skomplikowanych (Pastwa-Wojciechowska, 1998). Praca z pacjentami, u których rozpoznano antyspołeczne zaburzenia osobowości, jest wyjątkowo trudna nie tylko ze względu na brak ściśle określonych czynników etiologicznych, ale przede wszystkim z powodu stopnia samego zaburzenia, jego charakteru oraz szczególnie niesprzyjającego zmianom przebiegu.

Nie ulega wątpliwości, że psychoterapia, która wymaga od pacjenta szczerego i aktywnego uczestnictwa, w przypadku jednostki antyspołecznej spotyka się z oporem oraz przeświadczeniem o braku potrzeby jakiejkolwiek formy pomocy oraz wsparcia. Osoby przejawiające antyspołeczne zaburzenia osobowości nie są ponadto zdolne do emocjonalnego wglądu, na którym tak bardzo zależy większości terapii opartych na dialogu. Jednostki te nie dążą więc do żadnych zmian w zakresie swojego funkcjonowania, a narcystycznie zniekształcony obraz własnej osoby nie wymaga od nich określania koncepcji własnej przyszłości (Kent, Hoffman, 2011).

Ostatecznie przyjąć więc można, że, jak stwierdzają Kent i Hoffman (2011), „osoby przejawiające antyspołeczne zaburzenia osobowości wykazują postawę opozycyjną w stosunku do przebiegu całego postępowania terapeutycznego, rolę pacjenta widzą w zdecydowanej pozycji niższości, a osobę terapeuty jako obiekt, który można oszukać lub wykorzystać". Tutaj pojawia się również kolejny niezwykle istotny aspekt - manipulacja i instrumentalizm. Jak się bowiem okazuje jednostka antyspołeczna terapię traktuje jako swoistą grę (Millon, Davis, 2005), opartą na tzw. zimnej kalkulacji uwzględniającej jedynie własne korzyści (Pastwa-Wojciechowska, 1998). Niewątpliwie podejście takie nie tylko nie sprzyja budowaniu oczekiwanej pozytywnej relacji terapeutycznej (Millon, Davis, 2005), 
ale, co najważniejsze w przypadku niewłaściwego podejścia terapeuty, doprowadzić może również do tzw. „skuteczniejszego drapieżnictwa” osób poddawanych interwencji (Clarkin i in., 2013).

Wszystkie tego typu trudności, choć powszechne w pracy z osobą antyspołeczną, nie stanowią jednak bariery nie do pokonania (Chakhssi i in., 2010). Najważniejsza jest tu pełna świadomość przebiegu zaburzenia oraz umiejętność odpowiedniego reagowania na zaistniałe, utrudniające przebieg terapii problemy. Podkreślenia wymaga tu również fakt, że analizując zakres i skuteczność pomocy niesionej osobom przejawiającym tak ciężkie zaburzenia osobowości, do jakich należą zaburzenia antyspołeczne, zasadniczym aspektem, jaki należy uwzględnić już na etapie planowania (niezależnie od jej przyjętej metody lub formy terapii), jest tzw. prowadzenie pacjenta, którego fundament stanowi środowisko (miejsce) udzielania pomocy psychologicznej. Niewątpliwie musi być ono gwarantem bezpieczeństwa zarówno dla pacjenta, jak i terapeuty (Clarkin i in., 2013).

\subsection{Strategie i metody oddziaływań terapeutycznych w świetle głównych nurtów psychologicznych}

Obecnie w zakresie postępowania psychoterapeutycznego stosowanego wobec jednostek antyspołecznych wyróżnia się wiele strategii i metod. Większość z nich czerpie jednak z dwóch fundamentalnych podejść psychologicznych: psychoanalizy oraz terapii poznawczo-behawioralnej.

\subsection{1. „Lęk, więź, sumienie”, czyli praca z jednostką antyspołeczną w nurcie psychoanalitycznym}

Jednym z pierwszych podejść, w którym podejmowano pracę terapeutyczną z osobami przejawiającymi antyspołeczne zaburzenia osobowości jest nurt psychoanalityczny, który bardzo wyraźnie podkreśla „rolę nieświadomych procesów, konfliktów i obron w funkcjonowaniu psychiki jednostki” (Gawda, 2011), jak również ich znaczenie dla postrzegania samego siebie oraz otaczającej rzeczywistości (Strelau, 2000). Na gruncie terapii psychodynamicznej za priorytetowy aspekt podejmowanego przez osoby antyspołeczne zachowania uznaje się więc te uwarunkowania, z których sama jednostka nie daje sobie sprawy, a które „sygnalizują zaburzenie w wewnętrznych stanach umysłu lub stanowią przed nimi obronę" (Clarkin i in., 2013).

$\mathrm{W}$ bezpośrednim odniesieniu do terapii podejście psychodynamiczne (Psychodynamic Therapy - PT) opiera się na dwóch zasadniczych celach: nauce „wglądu w siebie” oraz wzmocnieniu rozwoju „superego” (Pospiszyl, 2000). 
Podkreślić należy jednak wyraźnie, że już ogólna znajomość cech charakterystycznych oraz przebiegu antyspołecznych zaburzeń osobowości wydają się wskazywać jednoznacznie na wysokie prawdopodobieństwo wystąpienia trudności w zakresie stosowania tego właśnie typu oddziaływań. Do zasadniczych problemów zalicza się tu wspomniane już dysfunkcje w zakresie umiejętności uświadamiania sobie własnych i cudzych stanów emocjonalnych (Gawda, 2011), niedostateczną motywację do pracy nad samym sobą oraz niedostrzeganie istoty problemu własnego funkcjonowania (Pospiszyl, 2000). Przyjmując ponadto, że „struktura problemów w nurcie psychoanalitycznym znajduje się na poziomie nieświadomym, pacjenci $\mathrm{z}$ antyspołecznym zaburzeniem osobowości mogą mieć wyraźnie utrudniony dostęp do ich rozpoznania, a co za tym idzie również zmiany w ich zakresie" (Beck i in., 2005).

Najprawdopodobniej dlatego właśnie pierwsze doniesienia dotyczące tego właśnie rodzaju terapii prowadzonej w odniesieniu do jednostek antyspołecznych oceniane były zdecydowanie pesymistycznie.

$\mathrm{Z}$ upływem czasu i prowadzeniem kolejnych badań zaczęto tu jednak odnotowywać pewne pozytywne zmiany. Jak przytacza Pospiszyl (2000), efektywność terapii w nurcie psychoanalitycznym potwierdziła m.in. M. Schmideberg (1978). Wspomniana autorka, opierając się na indywidualnych opisach przypadków, wykazała zdecydowaną poprawę funkcjonowania u jedenastu niebezpiecznych sprawców przestępstw, którzy wykazywali „zanik poczucia winy i umiejętności nawiązywania kontaktu emocjonalnego z innymi ludźmi”.

Na pozytywne wskaźniki stosowania psychoanalizy wskazała również Pastwa-Wojciechowska (2006, 2009), która dokonała szeroko zakrojonego przeglądu badań nad skutecznością oddziaływań psychodynamicznych u osób antyspołecznych. Wspomniana autorka na podstawie analizy szeregu badań empirycznych wielu autorów wykazała, że pozytywne efekty oddziaływań terapeutycznych odnotowane zostały w 59\% terapii prowadzonych w latach 1962-1985. Szczególnie istotne jest tu jednak, że warunkiem koniecznym do pojawienia się korzystnych zmian w badanej grupie osób było prowadzenie systematycznych oddziaływań przez okres ok. 5-6 lat. Pozytywne rezultaty wyróżnione przez Pastwę-Wojciechowską na podstawie przeglądu prowadzonych terapii wskazują na:

- brak wrogości,

- większe uspołecznienie i uwewnętrznienie norm moralnych,

- poprawę w zakresie funkcjonowania sfery interpersonalnej,

- nawiązanie silniejszych więzi emocjonalnych z rodziną,

- podejmowanie i utrzymywanie pracy,

- zwiększenie stopnia wglądu w siebie (Pastwa-Wojciechowska, 2006; 2009).

Chociaż niewątpliwie stwierdza się więc możliwość uzyskania pozytywnych efektów psychoterapii psychodynamicznej stosowanej wobec osób przejawiających antyspołeczne zaburzenia osobowości, koniecznym wydaje się określenie warunków niezbędnych do ich zaistnienia. 
Przyjmuje się, że punktem wyjścia w zakresie stosowania terapii w nurcie psychoanalitycznym jest gruntowna ocena diagnostyczna pacjenta. Na jej podstawie wyodrębnić można bowiem te aspekty funkcjonowania jednostki, które rokują pozytywnie bądź też negatywnie w zakresie prognozy oraz oceny skuteczności planowanej interwencji. Jak podają Clarkin i in. (2013), do korzystnych kryteriów selekcyjnych należą tu:

- niski i umiarkowany poziom psychopatii,

- obecność lęku i/lub depresyjnego afektu,

- pewne zdolności do tworzenia relacji przywiązaniowych z innymi ludźmi w przeszłości,

- występowanie mechanizmów obronnych wyższego poziomu lub neurotycznych,

- pewne oznaki superego.

Analogicznie wyodrębnić można również te aspekty funkcjonowania poznawczego i emocjonalnego, które w dużym stopniu minimalizują skuteczność, a tym samym zasadność zastosowania u jednostki antyspołecznej terapii psychodynamicznej. Są to:

- „sadystyczno-agresywne zachowania prowadzące do poważnych obrażeń,

- zupełny brak wyrzutów sumienia lub usprawiedliwienia dla tego rodzaju zachowań,

- ponadprzeciętna inteligencja lub umiarkowane upośledzenie umysłowe,

- brak zdolności do tworzenia emocjonalnych przywiązań w przeszłości,

- nieoczekiwany atawistyczny strach odczuwany przez doświadczonego klinicystę w obecności pacjenta" (Meloy, 2002; Clarkin i in., 2013).

Ostatecznie przyjąć więc można, że w klinicznej ocenie zasadności prowadzenia terapii psychodynamicznej wobec osób przejawiających antyspołeczne zaburzenia osobowości kluczową rolę odgrywa występowanie u nich trzech zasadniczych aspektów: lęku, więzi oraz sumienia (Clarkin i in., 2013).

Chociaż fundamentalne zasady psychoanalizy początkowo nie sprzyjały optymizmowi w zakresie roli terapii psychodynamicznej w pracy z osobami antyspołecznymi (King i in., 2005), to jednak późniejsze badania nad dysfunkcjami poznawczymi oraz przetwarzaniem afektywnym pacjentów antyspołecznych wraz z uwzględnieniem faktu, że antyspołeczne zaburzenia osobowości uznane zostały za zaburzenia przywiązania (Clarkin i in., 2013) świadczyć mogą o dużej wartości terapii psychodynamicznej.

Jak podkreślają ponadto King i in. (2005), terapie prowadzone w nurcie psychoanalitycznym największą wartość niosą dla tych osób, których motywacja do leczenia wykracza poza chęć rozwiązania natychmiastowego problemu i które szukają zwiększenia świadomości ukrytych źródeł doświadczenia i zachowania. Ponadto, wyraźnie podkreślić należy tu również, że na efektywność interwencji psychodynamicznej wskazuje się przede wszystkim w połączeniu z innymi metodami oddziaływań (King i in., 2005). 


\subsubsection{Praca $\mathrm{z}$ jednostką antyspołeczną $\mathrm{w}$ nurcie poznawczo-behawioralnym}

Kolejnym, a przy tym zdecydowanie lepiej postrzeganym na gruncie praktyki klinicznej, podejściem terapeutycznym stosowanym w odniesieniu do jednostek antyspołecznych jest nurt poznawczo-behawioralny.

Fundamentem tego podejścia są dwie koncepcje pracy terapeutycznej: skoncentrowanie na obserwowalnym zachowaniu - behawioryzm oraz oparta na przetwarzaniu informacji - terapia poznawcza. W modelu tym zakłada się więc związek między indywidualnymi przekonaniami i emocjami danej jednostki, a podejmowaną przez nią aktywnością i działaniem (Opora, 2010).

Terapia kognitywno-behawioralna (Cognitive Behavioral Therapy - CBT) wydaje się być szczególnie właściwym rozwiązaniem w zakresie leczenia wszelkich zaburzeń osobowości (Matusiewicz, 2010). Nie powinien dziwić więc fakt, że z tego typu interwencji korzysta się także w postępowaniu z jednostkami antyspołecznymi, u których poprzez pracę nad funkcjonowaniem poznawczym dąży się do poprawy zachowań moralnych i społecznych (Beck i in., 2005). Bardzo istotne jest jednak, żeby leczenie było tu czymś więcej niż tylko instrumentalnym środkiem, przez który dana osoba stara się osiągnąć własne korzyści. Między innymi dlatego właśnie tak dużą rolę przypisuje się tu zaangażowaniu pacjenta oraz właściwej relacji terapeutycznej (Seligman i in., 2003). Istotnym jest również fakt, że leczenie na gruncie terapii poznawczo-behawioralnej opiera się na pracy nad obserwowalnym zewnętrznie zachowaniem oraz jego wyznacznikami, np. agresją bądź uzależnieniami, a nie jak w przypadku terapii psychodynamicznej na dążeniu do poprawy zaburzonej struktury osobowości (Clarkin i in., 2013).

$\mathrm{W}$ praktyce klinicznej zalety terapii poznawczo-behawioralnej dostrzegli m.in. Davidson i in. (2009), którzy badali skuteczność tej właśnie formy oddziaływań u osób antyspołecznych przejawiających agresję. 52 dorosłych mężczyzn z rozpoznaniem antyspołecznych zaburzeń osobowości (a przy tym przejawiających agresję w okresie 6-ciu miesięcy poprzedzających badania) zostało losowo przydzielonych do leczenia standardowego (TAU) oraz leczenia metodami standardowymi poszerzonymi o terapię poznawczo-behawioralną $(T A U+C B T)$. Chociaż (po 12 miesiącach obserwacji) w obu badanych grupach odnotowano spadek wystąpienia aktów agresji - słownej i fizycznej, to jednak pojawiły się tu również dane przemawiające za bezpośrednio korzystnym wpływem terapii poznawczo-behawioralnej. Pozytywne zmiany po zastosowaniu $C B T$ odnotowano w zakresie ograniczenia używania alkoholu, poprawy funkcjonowania społecznego oraz korzystnej zmiany przekonań o innych, co sugeruje, że zastosowana tu forma terapii nie pozostaje bez znaczenia dla ogólnej poprawy funkcjonowania jednostek antyspołecznych. 
Efektywność terapii kognitywno-behawioralnej potwierdzają również inni badacze Cullen i in. (2012), którzy przeprowadzili badania wśród 84 hospitalizowanych na oddziałach sądowych sprawców przestępstw przejawiających zaburzenia psychiczne oraz wykazujących zachowania antyspołeczne i przemoc. Uczestnicy badania zostali losowo przydzieleni do Programu Umiejętności Poznawczych (the Reasoning and Rehabilitation $-R \& R$ ) oraz leczenia standardowego (TAU). Przypadki wystąpienia przemocy i zachowań antyspołecznych oceniano tu zarówno w trakcie leczenia, jak i po 12 miesiącach od jego zakończenia. Wyniki badań wskazują wyraźnie, że w grupie osób biorącej udział w terapii, która ukończyła pełny program leczenia, incydenty agresji werbalnej, przemocy i naruszeń norm były istotnie niższe w stosunku do grupy leczonej standardowo. Znaczące pozytywne skutki odnotowane zostały tu nie tylko w trakcie realizacji programu $R \& R$, ale również w rok po jego zakończeniu. Rezultaty te są wyjątkowo zachęcające i wskazują, że przestępcy z zaburzeniami psychicznymi, którzy brali udział w pełnej, intensywnej i systematycznej interwencji kognitywno-behawioralnej, mogą wykazywać poprawę w zakresie niwelowania postaw przestępczych, w tym redukowania zachowań destrukcyjnych, jak również rozwiązywania problemów społecznych i umiejętności radzenia sobie ze stresem. Co jest tu szczególnie istotne, program umiejętności poznawczych miał także niepodważalny wpływ na znaczne zmniejszenie recydywy w populacji antyspołecznych przestępców (Cullen i in., 2012).

Ostatecznie przyjąć więc można, że pomimo wyraźnej potrzeby prowadzenia dalszych badań nad efektywnością terapii poznawczo-behawioralnej w odniesieniu do jednostek przejawiających antyspołeczne zaburzenia osobowości już teraz wyraźnie wskazuje się na skuteczność stosowanych na jej gruncie metod. Do szczególnie istotnych sposobów interwencji zalicza się tu m.in.

- ,inicjowanie pracy nad problemem;

- szukanie związku zniekształconych myśli z zachowaniami dezadaptacyjnymi;

- budowanie umiejętności radzenia sobie w problematycznych sytuacjach;

- usystematyzowane podejście do problemu złości i impulsywności;

- samoobserwację i funkcjonalną motywację;

- rozszerzanie podstaw do dokonywania atrybucji i ocen;

- podejmowanie konstruktywnych decyzji” (Beck i in., 2005).

Wspomnieć warto także, że pozytywne zmiany, do których dąży się w zakresie stosowania terapii poznawczo-behawioralnej jednostek antyspołecznych, to:

- ,poprawa umiejętności społecznych;

- zwiększenie samokontroli;

- zwiększenie krytycznego myślenia o sobie samym;

- poprawa umiejętności przyjęcia perspektywy społecznej;

- uświadomienie przeżyć ofiar przestępstw; 
- panowanie nad gniewem;

- zwiększenie umiejętności zawodowych;

- rozwiązywanie problemów interpersonalnych;

- zmiana postaw antyspołecznych;

- leczenie uzależnienia od substancji psychoaktywnych;

- osłabienie kontaktów z antyspołecznymi rówieśnikami;

- poprawa pozytywnych interakcji z rówieśnikami, którzy nie mają postaw antyspołecznych" (Carson i in., 2003).

Ostatecznie przyjąć więc można, że zasadniczym celem terapii poznawczo-behawioralnej jednostek antyspołecznych jest poprawa „moralnych i społecznych zachowań pacjenta", do której dąży się poprzez pracę nad jego funkcjonowaniem poznawczym, a nie rozwój moralnej struktury opartej na lęku czy poczuciu winy. Innymi słowy, terapia ta uznana będzie za skuteczną, jeżeli w jej wyniku osoba z antyspołecznym zaburzeniem osobowości nauczy się uwzględniać perspektywy innych ludzi oraz uwzględniać będzie możliwe przekonania i zachowania (Beck i in., 2005).

\subsubsection{Najnowsze podejścia terapeutyczne $w$ pracy $z$ osobami przejawiającymi antyspołeczne zaburzenia osobowości}

Biorąc pod uwagę fakt, że na przestrzeni ubiegłych lat szczególną uwagę zwrócono na skuteczność terapii u osób przejawiających ciężkie zaburzenia osobowości (w tym zaburzenia antyspołeczne), nie powinno dziwić, że na gruncie dotychczas stosowanych metod terapeutycznych wyłoniły się nowe, szczególnie znaczące podejścia terapeutyczne.

Tym samym z założeń nurtu psychoanalitycznego wyodrębniły się dwie pozytywnie rokujące strategie oddziaływań, do których zalicza się: terapię opartą na mentalizacji (Mentalization-Based Treatment-MBT) oraz terapię skoncentrowaną na przeniesieniu (Transference-Focused Psychotherapy - TFP). Na gruncie założeń poznawczo-behawioralnych pojawiły się z kolei: dialektyczna terapia behawioralna (Dialectical Behavior Therapy - DHT) oraz terapia zorientowana na schematy (Schema Therapy - ST) (Clarkin i in., 2013).

\section{Terapia oparta na mentalizacji}

Terapia oparta na mentalizacji, opracowana przez Batemana i Fonagy'ego (2004) bazuje na założeniu, że nasze stany umysłowe warunkowane są zarówno wewnętrznie, jak i zewnętrznie, a na skutek utworzonej reprezentacji umysłowej podejmujemy odpowiednie działanie (Clarkin i in., 2013). Mentalizacja postrzegana tu jako umiejętność rozumienia stanów umysłowych niewątpliwie stanowi 
podstawowy aspekt relacji międzyludzkich, który z kolei umożliwia jednostce utożsamianie własnych działań oraz działań innych ludzi w ujęciu intencjonalnych myśli, potrzeb, uczuć oraz pragnień, a który zostaje wysoce ograniczony na skutek zakłóconej i wysoce zdezorganizowanej w dzieciństwie relacji przywiązania (ibidem, 2013). Istotne jest, że według tego podejścia źródłem zaburzeń $\mathrm{w}$ funkcjonowaniu jednostki są nieprawidłowości w zakresie relacji powstałych we wczesnych okresach życia między dzieckiem a osobą, z którą dziecko to wytwarza więź (Gawda, 2011). Co ponadto istotne, wykształcenie u jednostki nieprawidłowych form przywiązania (co niewątpliwie ma miejsce w przypadku osób przejawiających antyspołeczne zaburzenia osobowości) odzwierciedla się w zniekształconym obrazie rzeczywistości, nieprawidłowym odbiorze bodźców z otoczenia oraz niewłaściwych mechanizmach asymilacyjnych, co w konsekwencji prowadzi do znacznych zaburzeń $\mathrm{w}$ zakresie wszelkich relacji interpersonalnych (Gawda, 2011).

Aktualnie przyjmuje się, że terapia $M B T$ przynieść może szczególnie dobre rezultaty w przypadku osób przejawiających znaczne deficyty w zakresie mentalizacji. Uznaje się ponadto, że w przebiegu stosowania tego typu terapii w odniesieniu do jednostek antyspołecznych powinno koncentrować się przede wszystkim na problemie nieprawidłowo wykorzystywanej mentalizacji (Clarkin i in., 2013), a nie próbie „uzupełnienia” deficytów powstałych w jej zakresie.

\section{Terapia skoncentrowana na przeniesieniu}

Terapia skoncentrowana na przeniesieniu podobnie jak terapia oparta na mentalizacji wywodzi się z nurtu psychoanalitycznego. Opiera się ona na teorii relacji z obiektem, a jej twórcy - Kernberg i in. przyjmują, że jednostka „cierpi na zespół dyfuzji tożsamości, wynikający z niewydolności integracji psychicznej, w którym agresywne zinternalizowane relacje $\mathrm{z}$ obiektem dominują nad idealizowanymi relacjami i oddzielają je od nich" (Clarkin i in., 2013). Innymi słowy, zakłada się tu, że obiekt niezbędny jest do rozwoju ego i self jednostki, a nieprawidłowa relacja z tym obiektem nie tylko prowadzi do niewłaściwego rozwoju self, co rzutuje bezpośrednio na błędne postrzeganie siebie w relacjach z innymi (Gawda, 2011), ale również prowadzi do tego, że ego fiksuje się na poziomie prymitywnym, co ostatecznie doprowadza do niskiej ,kontroli impulsów, niestabilnych relacji i chaotycznego stylu życia" (Clarkin i in., 2013).

Chociaż, jak już wspomniano, obecnie uznaje się słuszność stosowania strategii terapeutycznych TFP w odniesieniu do pracy z jednostkami antyspołecznymi, to jednak podkreślenia wymaga tutaj fakt, że oddziaływania prowadzone $\mathrm{w}$ tym nurcie niosą ze sobą pewne ograniczenia. Jak bowiem podają wspomniani twórcy, teoria ta okazuje się najbardziej skuteczna w stosunku do osób przejawiających łagodny oraz umiarkowany poziom psychopatii, podczas gdy jednostki antyspołeczne o szczególnie silnym nasileniu cech psychopatycznych zostają z niej wykluczone. 


\section{Terapia dialektyczno-behawioralna}

Terapia dialektyczno-behawioralna opracowana przez Linehan $i$ in. wywodzi się z gruntu terapii poznawczo-behawioralnych. Linehan prezentuje powstawanie zachowań destrukcyjnych i autodestrukcyjnych w ujęciu modelu biospołecznego, gdzie zaburzenia uwarunkowane są wzorcami poznawczo-emocjonalnymi (Gawda, 2011). Wspomniana autorka podstaw pojawienia się zaburzeń osobowości upatruje więc $\mathrm{w}$ wielu zróżnicowanych czynnikach, do których zalicza m.in. indywidualne różnice wrażliwości na dysregulację emocjonalną czy też interakcje jednostki ze środowiskiem (Miller i in., 2011).

W zakresie oddziaływań terapeutycznych dialektyka odnosi się do pracy poprzez perswazję, a stosowany tu program leczenia bazuje na pięciu zasadniczych funkcjach obejmujących swoim zakresem: „zwiększanie motywacji pacjenta do wprowadzania zmian, kształtowanie nowych umiejętności, wdrażanie nowych zachowań, nadawanie struktury środowisku oraz wzmacnianie motywacji i umiejętności terapeuty" (ibidem, 2011).

\section{Terapia zorientowana na schematy}

Terapia schematów stanowi jedno z najbardziej integracyjnych podejść terapeutycznych, które, mając podłoże na gruncie teorii poznawczo-behawioralnych, swoim zakresem obejmuje również: teorię przywiązania, Gestalt, relacji z obiektem, konstruktywizmu oraz elementy oddziaływań psychoanalitycznych (Young i in., 2013). Jest to ponadto terapia szczególnie ceniona w przypadku leczenia ciężkich zaburzeń osobowości.

W ujęciu terapii schematów osobowość pojmowana jest jako swoisty system schematów, którego poszczególne podsystemy odpowiedzialne są za przetwarzanie informacji (Gawda, 2011). Istotne jest, że schematy te kształtują się już w okresie dzieciństwa i mają swoje odzwierciedlenie m.in. w zachowaniu, myślach czy też emocjach danej jednostki (Madej, 2010). W przypadku osobowości zaburzonej mamy do czynienia ze schematami dysfunkcjonalnymi, które stanowią integralną część struktur poznawczych.

Istotne jest, że u jednostek antyspołecznych przy dominujących schematach wrogości i drapieżności istnieją nie w pełni rozwinięte schematy miłości oraz szacunku, co ostatecznie skutkuje nieprawidłowym postrzeganiem otaczającej rzeczywistości, niewłaściwym wyrażaniem myśli i emocji, a w konsekwencji rzutuje negatywnie na podejmowane działanie (Gawda, 2011). Oddziaływania terapeutyczne proponowane w tym modelu ukierunkowane są więc na tzw. „uleczenie schematu" (które w ujęciu autorów opisywanej tu teorii stanowią rdzeń zaburzeń osobowości). Interwencja swoim zakresem obejmuje tu wszystkie aspekty nieprawidłowych schematów i rozwiniętych na ich podstawie strategii funkcjonowania, tj. sferę poznawczą, afektywną i behawioralną (Joung i in., 2013), co ma szczególne znaczenie w przypadku jednostek antyspołecznych, których schematy i rozwinięte w ich zakresie dominujące strategie są wyjątkowo nieprawidłowe. 


\subsubsection{Modalność terapii w kontekście skuteczności prowadzonej interwencji}

Poza wyborem odpowiedniego modelu terapeutycznego, w pracy z osobami przejawiającymi antyspołeczne zaburzenia osobowości szczególnie istotne jest również uwzględnienie tzw. modalności terapii, tj. formy, w jakiej będzie ona prowadzona. W zakresie pomocy terapeutycznej jednostek z osobowością zaburzoną dominują cztery możliwe formy prowadzonych oddziaływań: forma indywidualna, grupowa, rodzinna bądź też wspólnota terapeutyczna (Clarkin i in., 2013).

Zaznaczyć warto, że w zakresie interwencji niesionej jednostkom antyspołecznym do szczególnie cenionych należy forma pracy grupowej, której ewentualnym uzupełnieniem mogą być spotkania indywidualne terapeuty z pacjentem. Terapie rodzinne znajdują tu natomiast zastosowanie $\mathrm{w}$ pracy $\mathrm{z}$ dziećmi przejawiającymi antyspołeczne zaburzenia zachowania (ibidem, 2013).

\section{Implikacje praktyczne}

Oddziaływania terapeutyczne stosowane w pracy z jednostkami przejawiającymi tak ciężkie zaburzenia osobowości, jakimi są zaburzenia antyspołeczne, niewątpliwie należą do najbardziej problematycznych procedur postępowania.

Punktem wyjścia w pracy z jednostką antyspołeczną (już na etapie planowania) jest zadbanie o tzw. środowisko pracy, które swoim zakresem niewątpliwie obejmować powinno bezpieczeństwo zarówno pacjenta, jak i terapeuty. Początek samej procedury leczenia upatruje się z kolei w dokonaniu wysoce precyzyjnej oceny stanu klinicznego oraz dogłębnej diagnozy, która ukierunkowana jest przede wszystkim na ustalenie stopnia „,nasilenia psychopatii, rozpoznanie wszelkich uleczalnych zaburzeń z osi I lub III oraz rozróżnienie tych cech osobowości, które mogą być podatne na leczenie", oczywiście z uwzględnieniem indywidualnych predyspozycji jednostki (Clarkin i in., 2013). W miarę możliwości wyróżnić należy tu również zarówno społeczne, jak i organiczne podłoże przejawianych zaburzeń (Radochoński, 2005). Do kolejnych aspektów pracy terapeutycznej zalicza się tu ponadto: uwzględnienie modalności terapii, określenie sposobu zaangażowania pacjenta $\mathrm{w}$ przebieg procesu terapeutycznego oraz wybór właściwego modelu oddziaływania (Clarkin i in., 2013).

Specyfika pracy z jednostkami antyspołecznymi sprawia, że szczególne znaczenie przypisuje się tu również odpowiedniemu, wielokontekstowemu przygotowaniu osoby podejmującej się prowadzenia interwencji - jego doświadczeniu, pełnej znajomości charakteru przejawianych dysfunkcji oraz, co wyjątkowo 
istotne, ich znaczenia dla bezpośredniego funkcjonowania jednostki. Do tego typu aspektów zalicza się więc m.in. świadomość faktu, że osoby antyspołeczne potrafią doskonale symulować poprawę swojego funkcjonowania (Pastwa-Wojciechowska, 1998), a ich koncentracja na narcystycznych i egocentrycznych skłonnościach może mieć niepodważalne znaczenie dla przebiegu całej terapii (Pospiszyl, 2000).

W postępowaniu terapeutycznym wskazuje się również na potrzebę uwzględniania odpowiedniego stopnia atrakcyjności i stymulacji prowadzonych oddziaływań (Ciosek, 2001) oraz podkreśla konieczność unikania bezpośrednich pytań o przeżywane przez jednostkę stany emocjonalne. Jak się bowiem okazuje osoby mające realne problemy z dostępem do tego typu treści mogą wykazać agresywne reakcje $\mathrm{w}$ obliczu potencjalnej konfrontacji z własnymi dysfunkcjami (Hesse, 2010).

Dodać można również, że terapia powinna mieć także ściśle określoną strukturę oraz być wysoce zintensyfikowana i systematyczna (Kent, Hoffman, 2011).

\section{Dyskusja i wnioski}

Fakt, że antyspołeczne zaburzenia osobowości opierają się na trwałych zmianach w zakresie popędów, uczuć i woli sprawia, że zarówno terapeutyczne, jak i resocjalizacyjne oddziaływania względem nich stosowane należą do jednych z najbardziej złożonych i skomplikowanych. Pomimo szeregu trudności, jakie pojawiają się tu przed klinicystami i przedstawicielami całego wymiaru sprawiedliwości, wyraźnie podkreślić należy, że nie są to jednak zaburzenia nieuleczalne. W rzeczywistości, coraz więcej badań sugeruje, że działania specjalistyczne, takie jak psychoterapie uzupełnione dodatkowo o programy leczenia zaburzeń współtowarzyszących (np. uzależnień), mogą być korzystne dla wielu osób z antyspołecznymi zaburzeniami osobowości. Obserwowane obecnie pozytywne zmiany w zakresie różnych form i metod oddziaływania, jak również próby usystematyzowania obowiązujących aktualnie kryteriów diagnostycznych pozwalają ponadto przypuszczać, że z czasem odnotowywane będą coraz bardziej efektywne zmiany w zakresie funkcjonowania jednostek antyspołecznych.

Omawiana tu problematyka wydaje się mieć priorytetowe znaczenie nie tylko dla indywidualnych jednostek, ale przede wszystkim dla całego społeczeństwa i jego ogólnego bezpieczeństwa. 


\section{Bibliografia}

Beck A. T., Freeman A., Davis D. D., Terapia poznawcza zaburzeń osobowości, Wydawnictwo Uniwersytetu Jagiellońskiego, Kraków 2005.

Bengt-Åke A., Tore H. A., Cognitive-behavioral treatment for antisocial behavior in youth in residential treatment, „Cochrane Database of Systematic Reviews” 2009, vol. 17, no 4.

Carson R. C., Butcher J. N., Mineka S., Psychologia zaburzeń, vol. 1, Gdańskie Wydawnictwo Psychologiczne, Gdańsk 2003, s. 526-546.

Chakhssi F., de Ruiter C., Bernstein D., Change during forensic treatment in psychopathic versus nonpsychopathic offenders, „The Journal of Forensic Psychiatry \& Psychology” 2010, vol. 21, no 5, s. 660-682.

Ciosek M., Psychologia sądowa i penitencjarna, Wydawnictwo Prawnicze PWN, Warszawa 2001, s. 207-208.

Clarkin J. F., Fonagy P., Gabbard G. O., Psychoterapia psychodynamiczna zaburzeń osobowości, Wydawnictwo Uniwersytetu Jagiellońskiego, Kraków 2013, s. 371-395.

Cullen A. E., Clarke A. Y., Kupiers E., Hodgins S., Dean K., Fahy T., A Multisite Randomized Trial of a Cognitive Skills Program for Male Mentally Disordered Offenders: Violence and Antisocial Behavior Outcomes, ,Journal of Consulting and Clinical Psychology” 2012, vol. 80, no 6, s. $1114-1120$.

Davidson K. M., Tyrer P., Tata P., Cooke D., Gumley A., Ford I., Walker A., Bezlyak V., Seivewright H., Robertson H., Crawford M. J., Cognitive behaviour therapy for violent men with antisocial personality disorder in the community: an exploratory randomized controlled trial, „Psychological Medicine", April 2009, vol. 39, no 4, s. 569-577.

Gawda B., Skrypty miłości, nienawiści i lęku u osób antyspołecznych, Wydawnictwo Difin, Warszawa 2011, s. 61-64.

Groth J., Oblicza psychopatii. Obraz kliniczny i kategorie diagnostyczne, Wydawnictwo Naukowe SCHOLAR, Warszawa 2010, s. 71.

Hesse M., What should be done with antisocial personality disorder in the new edition of the diagnostic and statistical manual of mental disorders (DSM-V)?, „Hesse BMC Medicine” 2010, 8:66, s. $1-4$.

Kent A. K., Hoffmann M. B., The criminal psychopath: history, neuroscience, treatment and economics, „The Journal of Law, Science \& Technology” 2011, vol. 51, no 4, s. 355-397.

King R., O'Brien T., Giacomantonio S. G., Psychoanalytic perspectives on substance use and antisocial personality disorder, „Australian Psychologist”, June 2005, vol. 40 (2), s. 137-145.

Madej A., Techniki i metody poznawczo-behawioralne w terapii schematu zaburzeń osobowości, „Psychoterapia” 2010, 1 (152), s. 53-66.

Matusiewicz A. K., Hopwood Ch. J., Banducci A. N., Lejuez C. W., The Effectiveness of Cognitive Behavioral Therapy for Personality Disorders, „Psychiatric Clinic of North America”, September 2010, vol. 33 (3), s. 657-685.

Miller A. L., Rathus J. H., Linehan M. M., Dialektyczna terapia behawioralna nastolatków z tendencjami samobójczymi, Wydawnictwo Uniwersytetu Jagiellońskiego, Kraków 2011, s. 52-57.

Millon T., Davis R., Zaburzenia osobowości we współczesnym świecie, Instytut Psychologii Zdrowia, Warszawa 2005, s. 142-146.

Opora R., Resocjalizacja: wychowanie i psychokorekcja nieletnich niedostosowanych społecznie, Oficyna Wydawnicza Impuls, Kraków 2010, s. 13-16.

Pastwa-Wojciechowska B., Diagnoza i funkcjonowanie „psychopatów” w warunkach izolacji więziennej, [w:] J. Szałański (red.), Wina - kara - nadzieja - przemiana. Materiały I Krajowego Sympozjum Penitencjarnego, Łódź-Warszawa-Kalisz 1998, s. 423-427. 
Pastwa-Wojciechowska B., Analiza współczesnej konceptualizacji pojęcia psychopatycznego sprawcy przestępstw na tle seksualnym, [w:] E. Martynowicz (red.), Od poczucia podmiotowości do bycia ofiara, Kraków 2006, s. 262-268.

Pastwa-Wojciechowska B., Psychopatia - prawda i mity w psychoterapii i resocjalizacji, [w:] R. Kościelak (red.), Problem niedostosowania społecznego - oddziaływania $w$ warunkach wolnościowych $i$ w izolacji penitencjarnej, Słupsk 2006, s. 140-148.

Pastwa-Wojciechowska B., Skuteczność resocjalizacji przestępców seksualnych o cechach psychopatycznych - przegląd badań, Warszawa 2009, s. 49-70.

Polaschek D. L. L., Ross E. C., Do early therapeutic alliance, motivation, and stages of change predict therapy change for high-risk, psychopathic violent prisoners?, „Criminal Behaviour and Mental Health" 2010, vol. 20, s. 100-111.

Pospiszyl K., Psychopatia, Wydawnictwo Akademickie „Żak”, Warszawa 2000, s. 105-110.

Radochoński M., Psychopatia, socjopatia i osobowość antyspołeczna: kontrowersje terminologiczne i diagnostyczne, [w:] F. Kozaczuk (red.), Zagadnienia marginalizacji i patologizacji życia społecznego, Wydawnictwo Uniwersytetu Rzeszowskiego, Rzeszów 2005, s. 119-132.

Scott S., Deciding whether interventions for antisocial behaviour work: Principles of outcome assessment, and practice in a multicentre trial, „European Child \& Adolescent Psychiatry” 2001, vol. 10 , s. I/59-I/70.

Seligman M. E. P., Walker E. F., Rosenhan D. L., Psychopatologia, Wydawnictwo Zysk i S-ka, Poznań 2003, s. 126-127.

Strelau J., Psychologia. Podręcznik akademicki, t. 1, Gdańskie Wydawnictwo Psychologiczne, Gdańsk 2000, s. 51-56.

Wciórka J., Kryteria diagnostyczne wedtug DSM-IV-TR, Wrocław 2000, s. 233-237.

Woodworth M., Porter S., In cold blood Characteristics of Criminal Homicides as a Function of Psychopathy, ,Journal of Abnormal Psychology” 2002, vol. 111, no 3, s. 436-445. 